\title{
Klasifikasi Penyakit Pada Citra Daun Jeruk Menggunakan Arsitektur MobileNet berbasis Mobile Platform
}

\author{
Riswandi $^{1}$, Rosmiati Jamiah ${ }^{2}$, Nisa Mardhatillah ${ }^{3}$, Hady Prasetya Hamid ${ }^{4}$ \\ 1,2,3,4 Teknik Informatika, Universitas Hasanuddin \\ ${ }^{1}$ riswandir19d@student.unhas.ac.id, ${ }^{2}$ jamiahro19d@student.unhas.ac.id, \\ ${ }^{3}$ mardhatillahn19d@student.unhas.ac.id, ${ }^{4}$ hamidhap19d@student.unhas.ac.id
}

Coprespondent Author : Riswandi

\begin{abstract}
The diagnosis of citrus leaf diseases is carried out through laboratory investigation by a plant pathologist by observing the symptoms that appear on the plant to assist citrus leaf farmers in providing appropriate treatment based on the symptoms that visible in the condition of citrus leaves. Citrus leaf disease classification using image processing methods can provide a fast and accurate reference diagnosis. This study proposed a deep learning approach using the MobineNet CNN architecture to perform classification tasks. This proposed method was evaluated using three categories of citrus leaf disease images namely normal, HLB, and CTV with an image input size $=150 \times 150$. The evaluation process was carried out using the RMSprof optimization algorithm with 0.001 learning rate, through a trending process using the binary cross entropy architecture of the sigmoid activation function. According to the experimental results, the performance of citrus leaf classification achieved $98 \%$ in training process at the epoch 15.
\end{abstract}

Keyword - Citrus Leaf Disease, CNN, Machine Learning, MobileNet.

Abstrak - Proses diagnosa penyakit pada tanaman daun jeruk umunya dilakukan melalui pemeriksaan laboratorium oleh seorang ahli patologi tumbuhan dengan melihat gejala visual yang timbul pada tanaman untuk membantu petani daun jeruk dalam memberikan pola penanganan yang tepat berdasarkan gejala yang nampak pada kondisi daun jeruk. Klasifikasi penyakit daun jeruk menggunakan metode pengolahan citra mampu memberikan referensi diagnosis yang cepat dan akurat. Penelitian ini mengusulkan pendekatan deep learning menggunakan arsitektur MobineNet CNN untuk melakukan klasifikasi. Metode pada penelitian ini dievaluasi pada citra penyakit daun jeruk dalam tiga kategori yaitu normal, HLB dan CTV dengan ukuran citra 150x150. Pengujian dilakukan dengan menggunakan algortima RMSprof optimize dengan learning rate 0.001 . Proses pelatihan menggunakan arsitektur Binary Cross Entropy fungsi aktivasi sigmoid. Hasi klasifikasi penyakit pada citra daun jeruk pada proses training mencapai tingkat akurasi 98\% pada epoch 15 .

Kata kunci - CNN, Machine Learning, MobileNet, Penyakit Daun Jeruk

\section{PENDAhUluan}

Deteksi penyakit pada tanaman memegang peranan yang sangat penting dalam bidang pertanian karena mampu mempengaruhi produktivitas tanaman. Proses pendeteksian yang cepat dan akurat sangat membantu para ahli patologi tumbuhan untuk memberikan diagnosis yang tepat juga membantu petani untuk menentukan penanganan yang tepat untuk setiap jenis penyakit. Perawatan yang tepat untuk setiap jenis penyakit tanaman sangat dibutuhkan karena jika penanganan tidak tepat maka akan menimbulkan efek yang serius pada tanaman yang akan mempengaruhi kualitas dan kuantitas hasil produksi. Oleh Karena itu, mendeteksi penyakit tanaman pada tahap awal dengan teknik deteksi penyakit secara otomatis sangat bermanfaat[1].

Pada umumnya deteksi penyakit pada tanaman jeruk dilakukan melalui uji laboratorium oleh ahli patologi tumbuhan. Para ahli membantu petani untuk mendiagnosis penyakit tanaman dengan melihat gejala visual yang terlihat pada tanaman daun jeruk, Namun petani sering mengalami kesulitan dalam mengakses fasilitas laboratorium terutama petani yang berada dipedesaan.

Penyakit pada daun jeruk disebabkan oleh bakteri, jamur dan virus. Citrus bacterial spot, Citrus Scab, Citrus Canker, Citrus Leprosies, Citrus CTV dan HLB masing-masing merupakan penyakit yang disebabkan oleh bakteri, jamur dan virus pada tanaman daun jeruk. Penyakit ini menyerang pada bagian daun, buah dan batang pada tanaman jeruk[2]. Karakteristik penyakit pada tanaman ini dapat diamati melalui noda atau bercak yang timbul pada buah atau daun. Penyakit Huanglongbin (HLB) menunjukkan gejala yang kompleks ditunjukkan dengan daun dan cabang yang menguning, daun tampat seperti telinga kelinci, terdapan bercak kuning pada pucuk, bitnik yang tidak teratur pada lamina daun, dan urat daun yang menguning. Sedangkan daun jeruk dengan gejala, sedangkan CTV (Citrus Tristeza Virus) menunjukkan gejala sayap tanaman yang menunjukkan gejala daun menguning yang jelas dan penampakan urat yang jelas[3].

Pada penelitian sebelumnya, penerapan Gray Level CoOccurrence Matrix (GLCM) memperoleh hasil yang baik menggunakan metode machine learning. Selain SVM, algoritma Artificial Neural Network (ANN) juga digunakan untuk mendeteksi penyakit pada tanaman tomat[4] dan pisang[1]. Selain itu, [5] menggunakan K-Nearest Neighbor $(\mathrm{KNN})$ untuk mendeteksi penyakit jeruk.

Menurut [6] CNN yang tersegmentasi akan memperoleh hasil yang lebih baik dibandingkan CNN normal. [6] melakukan segmentasi menggunakan model CNN pada 10 
penyakit tanaman berbeda dengan tingkat akurasi 98.6\%. [7] mengusulkan sistem klasifikasi penyakit jeruk menggunakan SVM. Akurasi yang dihasilkan pada penelitian ini masing-masing $97 \%, 89 \%$, dan $90,4 \%$ pada dataset bersumber dari internet, gabungan dataset daun jeruk dan dataset daun jeruk lokal. [8] mengombinasikan CNN dan SVM untuk melakukan klasifikasi 4 jenis penyakit pada daun padi. Proses ekstraksi citra dilakukan dengan menerapkan arsitektur AlexNet CNN dan menghasilkan tingkat akurasi $97.29 \%$ pada proses klasifikasi.

Pada penelitian ini, diagnosa penyakit pada citra daun jeruk dilakukan dengan menerapkan arsitektur MobileNet pada algoritma Convolutional Neural Network (CNN) untuk identifikasi dan klasifikasi penyakit pada citra daun jeruk secara real-time berbasis citra smartphone. Kumpulan gambar jeruk yang sama digunakan untuk melakukan validasi model. Peneliti memilih MobileNet CNN sebagai model dasar karena sifat model yang ringan untuk aplikasi telepon pintar. Sehingga model yang diusulkan dapat memberikan kontribusi terhadap identifikasi dan klasifikasi penyakit pada citra daun jeruk secara real-time.

\section{MATERIAL DAN METODE}

\section{A. Dataset}

Dataset didapatkan melalui hasil pengumpulan data secara pribadi dari beberapa tanaman daun jeruk yang berlokasi di kota Makassar dan kabupaten Gowa Sulawesi Selatan. Citra diambil menggunakan perangkat smartphone. Citra dibagi menjadi tiga kategori, yaitu daun jeruk normal, CTV dan HLB. Dataset yang digunakan pada penelitian ini berjumlah 90 data dengan jumlah daun jeruk normal sebanyak 32 data, HLB sebanyak 39 data dan 19 data untuk daun jeruk terjangkit CTV dengan perbandingan $80 \%$ data digunakan untuk proses training model dan $20 \%$ proses testing.
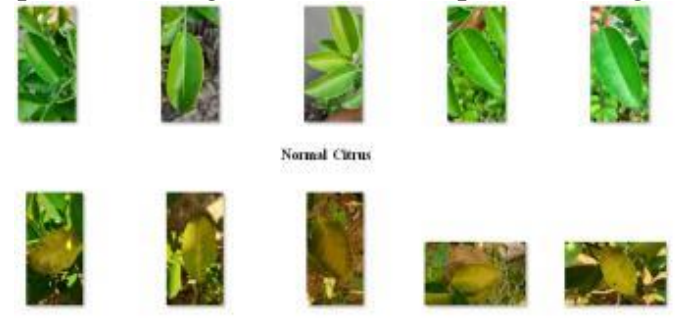

$$
\text { cTV Cims }
$$
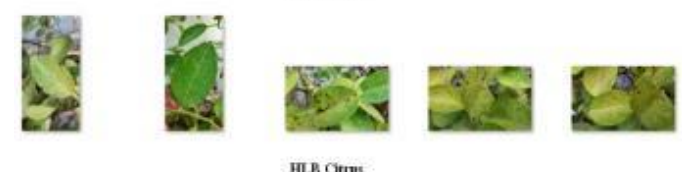

Gambar 1. Citra daun jeruk normal, CTV dan HLB

\section{B. Perangkat}

Citra daun jeruk diambil menggunakan perangkat smartphone dengan spesifikasi sebagai berikut :

1) Device SAMSUNG M20
2) Kamera 13 Megapiksel

3) Aperture f/1.9 PDAF

\section{Pengolahan Citra Daun Jeruk}

Pada tahap ini citra daun jeruk dilakukan pengubahan ukurannya citra ke dimensi 150x150. Gambar ditambah dengan ukuran batch 64 untuk meningkatkan jumlah gambar dalam set validasi. 75 gambar termasuk dalam set training, setelah segmentasi 75 gambar direkam dalam set training. model diimplementasikan di lingkungan GPU Google Collab menggunakan keras dan tensorflow.

\section{Klasifikasi Penyakit Daun Jeruk Menggunakan Arsitektur Mobilenet CNN.}

Proses klasifikasi pada MobileNet CNN dibuat blok berisi lapisan ekspansi $(2 \times 2)$, lapisan konvolusi kedalaman (3x3), yang dibuat sebanyak 3 blok secara berurutan untuk proses konversi satuan bit gambar dari 16, 32 dan 64 filter, sehingga terdapat 6 proses berlangsung sebelum masuk dalam proses layer dan diklasifikasi melalui lapisan 512 hidden layer dan ke layer berikutnya yang berisi aktivasi sigmoid untuk menentukan hasil akhir gambar. Diagram blok pada penelitian ini ditunjukkan pada gambar 2:

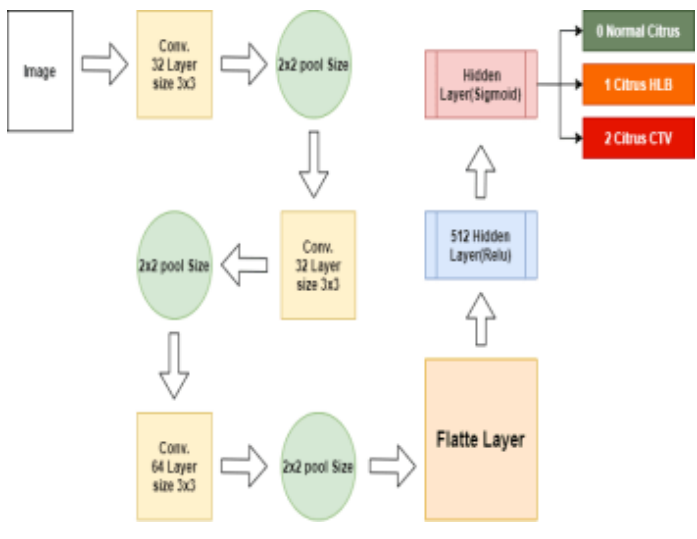

Gambar 2. Diagram blok MobileNet CNN yang diusulkan

Model dioptimalkan dengan pengoptimal RMSProp (Root Mean Square Propagation) dengan kecepatan pembelajaran 0,001. Menggunakan kategorikal binary cross-entropy, akurasi dan kerugian model dievaluasi selama 10 epoch. dengan algoritma sebagai berikut:

1) Langkah 1: Data Gambar dari proses MobileNet masuk Tensor Hub.

2) Langkah 2: menambahkan layer konvolusi $3 \times 3$ dengan filter bit 16,32,64 dan pool 2x2

3) Langkah 3: Tambahkan Flatte Layer

4) Langkah 4: Tambahkan hidden layer dengan 512 neuron tersembunyi di model

5) Langkah 5: Tambahkan hidden layer terakhir dengan 3 neuron dengan aktivasi sigmoid.

Dari model yang telah dibuat didapatkan beberapa parameter pada tiap layer dan parameter pada setiap layer : 


\begin{tabular}{|c|c|c|}
\hline Layer (type) & Output Shape & Paran \\
\hline Input_1 (Inputtayer) & [ (Gone, $150,150,3)]$ & 0 \\
\hline conv2d (Conv2D) & (None, 148, 148, 16) & 448 \\
\hline nax_pooling2d (MaxPooling2D) & (None, 74, 74, 16) & 0 \\
\hline conv2d_1 (Conv2D) & (None, 72, 72, 32) & 4640 \\
\hline nax_pooling2d_1 (Maxpooling2 & (None, 36, 36, 32) & 0 \\
\hline Conv2d_2 (Conv2D) & (None, 34, 34, 64) & 18496 \\
\hline nax_pooling2d_2 (MaxPooling2 & (None, 17, 17, 60) & 0 \\
\hline flatten (Flattea) & (None, 18496) & 0 \\
\hline dense (Dense) & (None, 512) & 9470464 \\
\hline dense_1 (Dense) & (None, 1) & 513 \\
\hline
\end{tabular}

Gambar 3. Model Parameter

\section{E. Aplikasi Android Untuk Pengujian Penyakit Daun Jeruk Secara Real Time}

Pada tahap awal pendeteksian penyakit daun jeruk pada, aplikasi untuk pengguna akhir sangat penting bagi petani jeruk. Untuk menerapkan model akan diimplementasikan pada smartphone android, model disimpan dalam .pb kemudian diubah menjadi ttflite menggunakan tensorflow lite konverter. Model .tflite yang disimpan dimuat secara terpisah di smartphone android menggunakan aplikasi (app) android. Aplikasi android dikembangkan menggunakan Flutter yang berbasis bahasa .dart gambar 4 merupakan file model dalam bentuk extensi .tflite dalam proyek aplikasi ini:

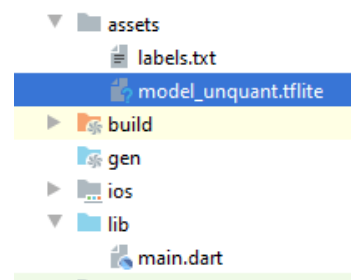

Gambar 4. File model Flutter dalam extensi . tflie

Pada perangkat smartphone android dilakukan proses penajaman citra secara otomatis agar gambar yang akan diproses pada model MobileNet akan lebih tajam dan ringan dalam proses upload dan konvolusi, adapun konfigurasi gambar sebelum proses klasifikasi pada cloud sebagai berikut:

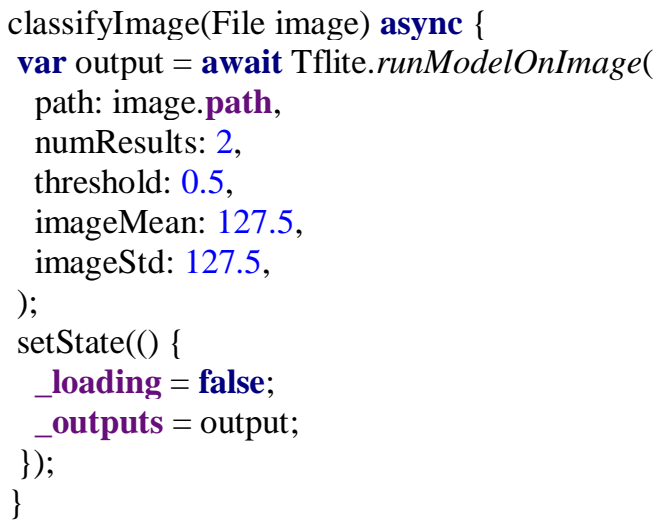

Diagram alir aplikasi secara keseluruhan adalah sebagai berikut :

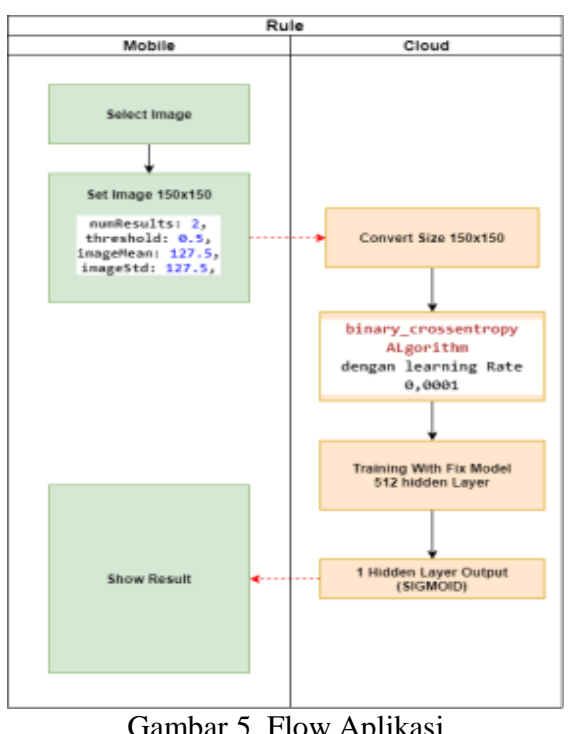

Desain aplikasi masih dibuat simple dan sederhana dengan tampilan halaman utama pada aplikasi deteksi penyakit pada citra daun jeruk ditunjukan pada gambar 6 :

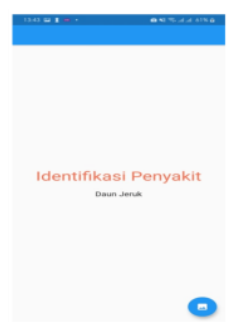

Gambar 6. Halaman utama aplikasi deteksi penyakit daun jeruk

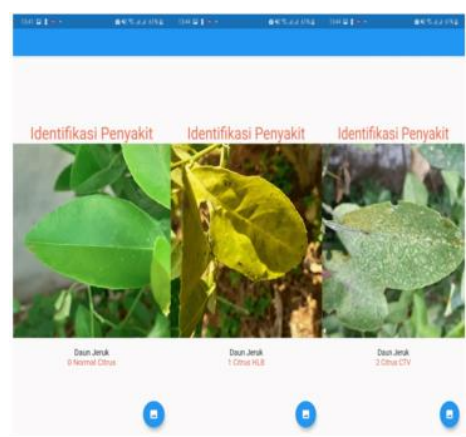

(b)

Gambar 7. Hasil klasifikasi penyakit pada citra daun jeruk (a) Tampilan Awal, (b) Output CTV, HLB Normal 


\section{HASIL DAN DISKUSI}

Pada tahap pengujian digunakan metode RMprop karena model yang akan diklasifikasi dalam bentuk biner maka model akan di training dengan binary crossentropy loss, dengan nilai RMSprop optimalize dengan learning rate 0.001 selama proses training dengan jumlah 15 epoch. Hasil tingkat akurasi akan ditampilkan dalam bentuk grafik pada gambar 7:
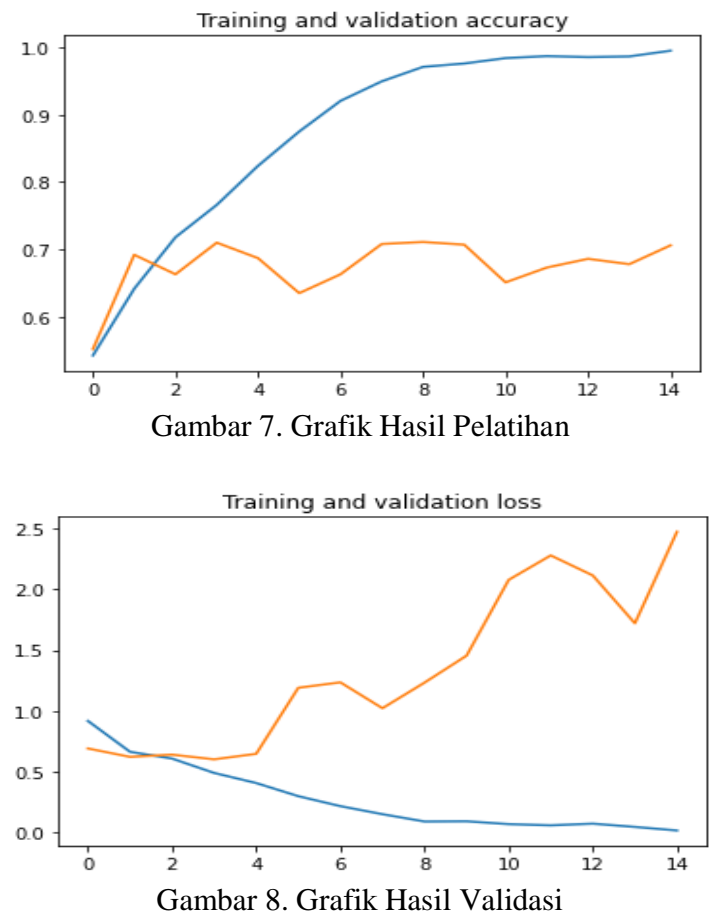

Hasil penelitian menunjukkan bawah tingkat akurasi mendekati sebesar $98 \%$ pada proses pelatihan, namun pada proses validasi akurasi menurun di kearah $70 \%$, hal ini dapat diakibatkan oleh jumlah data set yang terlalu kecil, sehingga pada proses testing model masih kurang memberikan akurasi yang baik untuk klasifikasi penyakit pada citra daun jeruk. Diperulkan data yang lebih banyak untuk meningkatkan tingkat akurasi pada proses testing.

\section{KESIMPULAN}

Peneliti memilih MobileNet CNN sebagai model dasar karena sifat model yang ringan untuk aplikasi telepon pintar.
Dari hasil pengujian klasifikasi penyakit pada daun tanaman jeruk menunjukkan bahwa dengan menggunakan arsitektur MobileNet, hasil yang di dapat memiliki tingkat akurasi yang baik pada proses training, sehingga aplikasi ini dapat digunakan untuk mendeteksi penyakit secara real time melalui pengamatan gejala fisik yang timbul pada daun jeruk. Aplikasi juga dapat berjalan secara stabil dan tidak berat dengan menggunakan pengolahan pada cloud API dari google collab. Namun, dibutuhkan lebih banyak data citra penyakit tanaman daun jeruk untuk meningkatkan akurasi pada hasil testing.

\section{DAFTAR ACUAN}

[1] V. Singh and A. K. Misra, "Detection of plant leaf diseases using image segmentation and soft computing techniques," Inf. Process. Agric., vol. 4, no. 1, pp. 41-49, 2017, doi: 10.1016/j.inpa.2016.10.005.

[2] "Home / Citrus Diseases." http://idtools.org/id/citrus/diseases/ (accessed Jun. 30, 2021).

[3] U. Barman, R. D. Choudhury, D. Sahu, and G. G. Barman, "Comparison of convolution neural networks for smartphone image based real time classification of citrus leaf disease," Comput. Electron. Agric., vol. 177, p. 105661, Oct. 2020, doi: 10.1016/j.compag.2020.105661.

[4] X. Wang, M. Zhang, J. Zhu, and S. Geng, "Spectral prediction of Phytophthora infestans infection on tomatoes using artificial neural network (ANN)," Int. J. Remote Sens., vol. 29, no. 6, pp. 1693-1706, 2008, doi: 10.1080/01431160701281007.

[5] S. Sankaran, A. Mishra, J. M. Maja, and R. Ehsani, "Visiblenear infrared spectroscopy for detection of Huanglongbing in citrus orchards," Comput. Electron. Agric., vol. 77, no. 2, pp. 127-134, Jul. 2011, doi: 10.1016/j.compag.2011.03.004.

[6] P. Sharma, Y. P. S. Berwal, and W. Ghai, "Performance analysis of deep learning CNN models for disease detection in plants using image segmentation," Inf. Process. Agric., vol. 7, no. 4, pp. 566-574, Dec. 2020, doi: 10.1016/j.inpa.2019.11.001.

[7] M. Sharif, M. A. Khan, Z. Iqbal, M. F. Azam, M. I. U. Lali, and M. Y. Javed, "Detection and classification of citrus diseases in agriculture based on optimized weighted segmentation and feature selection," Comput. Electron. Agric., vol. 150, pp. 220-234, Jul. 2018, doi: 10.1016/j.compag.2018.04.023.

[8] V. Shrivastava and M. Pradhan, "Rice plant disease classification using color features: a machine learning paradigm," J. Plant Pathol., vol. 103, Oct. 2020, doi: 10.1007/s42161-020-00683-3. 